\title{
Decision Support System for Household Labor Services Selection "Best Helper" Using AHP and TOPSIS Methods
}

\author{
I Kadek Aditya Pirnanda ${ }^{1}$, I Made Ardwi Pradnyana ${ }^{2}$, I Made Agus \\ Wirawan $^{3}$ \\ ${ }^{1,2,3}$ Informatics Education Departement, FTK, Universitas Pendidikan Ganesha Singaraja, Indonesia \\ Email: ${ }^{1}$ adityapirnanda@gmail.com, ${ }^{2}$ ardwi.pradnyana@undiksha.ac.id, \\ 3imade.aguswirawan@undiksha.ac.id
}

\begin{abstract}
Selection of household labor services was an important aspect in families who have a lot of activity. The existence of helpful household labor services would avoid the occurrence of problems that should be caused. Types of household labor services which were often used were maids, baby sitters, elderly nurses, gardeners, and drivers. The main problem arose in the difficulty of service seekers in choosing the desired service and how to minimize the time spent. To overcome this, a decision support system was used using the Analytical Hierarchy Process (AHP) method which was used to find the criteria for each alternative weight, and ranking calculations using the Technique for Order of Preference by Similarity to Ideal Solution (TOPSIS) method. This research was implemented using PHP language with CodeIgniter framework. The result shows that the usability test obtains the average value with the system usability scale (SUS) method of $71.09 \%$. It shows that the level of system usability is classified as good and can be accepted and used easily by the users. Meanwhile, the result of the user response test shows a percentage of $87.5 \%$, so it can be concluded that the system belongs to good category and feasible to use.
\end{abstract}

Keywords: Household Labor Services, Decision Support System, AHP, TOPSIS

\section{INTRODUCTION}

Along with increasing family needs that must be fulfilled, increasingly encouraging women to participate in working with their husbands to help fulfill family needs. The time that couples have in taking care of their children and household work certainly decreases with the amount of time spent working outside the home. The difficulty of balancing work and family matters can cause problems that can interfere with work performance. From the existence of the problems posed, it results in the increasing need to use business in the field of services that can help various jobs that exist within the household sphere. The presence of services to help work in the household environment is very important 
in carrying out productive roles, so that the husband and wife can work quietly without being bothered by household affairs and finally be productive in their work.

Services are all activities and various activities or benefits offered to be sold by a party to another party, essentially these services are intangible and do not produce ownership transfers for anything [1]. Viewed from the environment and business aspects, business in the service sector is the most extensive type of business compared to other types of services. The type of business in the service sector relies more on service quality as an effort to provide satisfaction to its customers by implementing a consumer-oriented strategy. Examples of types of household labor services that are often used such as, baby sitters, helpers, elderly nurses, gardeners, and drivers.

Labor selection is needed by prospective users of domestic labor services because there are many labor services offered. In addition, the selection of labor services requires prospective service users to choose well and thoroughly. This is because the domestic workforce services will work in the household sphere of the employer. From the results of observations and interviews, it was found that the ideal conditions in the selection of domestic labor services are (1) providing detailed data on the services offered, (2) providing the best service options to make it easier for prospective service users to choose, (3) a brief in search so that the time the prospective user of domestic labor services is not much spent in choosing services.

From the initial observations that the researchers made through the distribution of questionnaires, interviews, and observations that the researchers conducted directly, it was found that in general the difficulties of service users in finding service for domestic workers were not yet aware of the attitudes and skills possessed by prospective workers. In seeking domestic worker services, most of the respondents were close friends / family, 21 respondents from 22 respondents were used for reliable reasons. Users of services that require domestic worker services also search directly through service providers. But not infrequently the services of domestic workers offered are not in accordance with the wishes of service users. In addition, there is also a lot of time, energy, and costs spent in search. Interviewing researchers with service providers / distributors shows that (1) the system used for each service provider / distributor still uses a conventional system in the form of a notebook for each workforce and employer data, (2) general criteria for selecting domestic workers based on last education, experience, costs / salary, attitudes, and skills, (3) The time needed for the selection of labor is quite long, because the selection is based on the advice of the distributor seen from the available workforce in accordance with the wishes of the service seekers. In addition, interviews conducted by researchers at the Buleleng Regency Manpower Office indicate that registered job seekers have an AK1 or yellow card used as a sign of looking for work, while in reality registering for 
employment as domestic worker services only requires ID cards. This raises a problem with government unemployment data.

Judging from the problems that exist, to solve it, a solution is needed that can (1) help service users in making quick and appropriate decisions in the selection of labor. (2) saving in terms of time, effort, and costs needed. (3) able to provide various alternatives in decision making. (4) can help service providers / distributors or individual workers to offer services. So the best solution to overcome this problem is the development of a decision support system (DSS) which can provide recommendations on the choice of domestic labor services to users of household labor services. Decision support system (DSS) is a system that is capable of providing problem solving and communication skills for problems with semi-structured and unstructured conditions [2].

In developing a support system for deciding the choice of household labor services, we need criteria for each alternative available. To determine it can use the multi criteria decision making method, one of them is the Analytical Hierarchy Process (AHP) method. The concept of the eigenvector in the AHP method can be used to carry out the priority weighting process of each criterion based on the pairwise comparison matrix [3]. Furthermore, the selection of household labor services can be overcome by using the Technique For Others method Reference by Similarity to Ideal Solution (TOPSIS). In the TOPSIS method, positive ideal values and negative ideal values will be calculated from each criterion and take the value of closeness relative to the positive ideal solution. The facilities that will be offered on the system that will be developed are (1) saving in terms of time, energy, and costs in selecting household labor services, (2) helping to provide recommendations on the best choices from domestic labor services to service seekers based on criteria, (3) help provide detailed information on the domestic labor services offered, (4) assist in promoting services both individually and through service providers / suppliers. In its implementation, this system will be developed based on websites by using responsive design to be feasible to be accessed from various types of devices. It is hoped that this system can help bring service seekers and service applicants together as expected.

\section{METHODS}

In designing and developing research decision support systems for the selection of "Best Helper" domestic labor services. The researcher used two different combination methods, namely the Analytical Hierarchy Process (AHP) and Technique For Others method Reference by Similarity to Ideal Solution (TOPSIS). AHP method is used to calculate the weight of each criteria and the TOPSIS method is used to calculate alternative ranking.

AHP method is able to provide more accurate information, because in this method the process is carried out pairwise comparisons between criteria and criteria, as well as sub-criteria and subcriteria [4]. AHP is a proven method for 
conducting pairwise comparisons in determining criteria weights [5]. One of the unique features of AHP is that it provides a powerful procedure to determine the relative importance of different attributes with respect to the objective [6]. In addition, the eigenvector concept possessed by the AHP method is also an advantage of this method for carrying out the priority weighting process for each criterion based on the pairwise comparison matrix [7]. Next, the TOPSIS method using the principle that the alternatives selected must have the shortest distance from the positive ideal solution and the farthest from the negative ideal solution from a geometrical point by using the Euclidean distance to determine the relative proximity of an alternative to the optimal solution [8].

The research method used in developing this system is the SDLC (System Development Life Cycle) method using the Linear Sequential Model / Waterfall Model. The model describes a systematic and sequential approach to the software developed. The following steps from the Waterfall Model are shown in Figure 1.

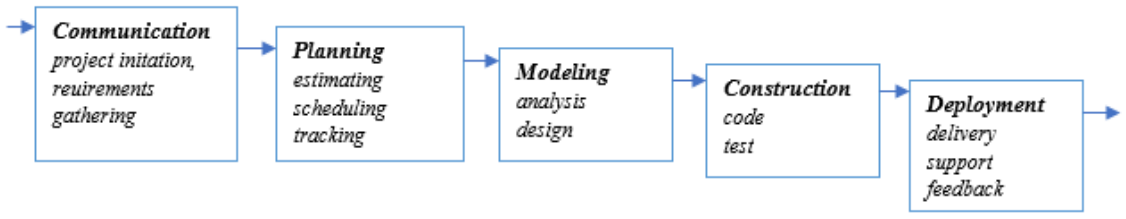

Figure 1. Waterfall Model Stage [9]

There are five stages in developing this system. First, at the communication stage researchers conduct information gathering through interviews, questionnaires, and direct observation to the field and planning stages to analyze the system's functional and non-functional needs. Furthermore, in the modeling phase, a system design is carried out that helps define the system architecture. The next stage is construction, at this stage the program code is made on the system and also testing the system to find out the system is running well. The last stage is the deployment stage, which is the stage for implementation of the stages that have been done before.

\subsection{Analytical Hierarchy Process (AHP)}

Analytical Hierarchy Process (AHP) is a functional hierarchy with the main input of human perception. This method was developed by Prof. Thomas Lone Saaty from Wharton Business School in the early 1970s, which was used to find ranking or priority order from various alternatives in solving a problem. This method uses complex problem solving techniques into small groups (hierarchies). The determination of grading each criterion is based on the following paired comparison scale. 
Table 1. Pairwise Comparison Scale [10]

\begin{tabular}{cl}
$\begin{array}{c}\text { Integrity of } \\
\text { Interest }\end{array}$ & \multicolumn{1}{c}{ Information } \\
\hline 1 & Both elements have the same important effect \\
3 & One element is a little more important than the other elements \\
5 & One element is more important than the other elements \\
7 & One element is clearly more important than the other elements \\
9 & The absolute element is more important than the other elements \\
$2,4,6,8$ & $\begin{array}{l}\text { Values between two values of adjacent considerations } \\
\text { If element i has one of the numbers above when compared to element } \mathrm{j} \text { has } \\
\text { the opposite when compared to element } \mathrm{i}\end{array}$ \\
\hline
\end{tabular}

Steps of the AHP method:

1. Arrange a hierarchy of problems

2. Determine pairwise comparison matrices

At this stage a comparison is made between elements by observing the elements at the level above. The first division is carried out for elements at the criteria level with regard to the scale of one to nine. At this stage a comparison is made between the criteria. Giving a comparison value based on a paired comparison scale.

$$
\sum_{j}^{i} a i j=1
$$

Information :

$\alpha=$ Pairwise comparison matrix

$\mathrm{i}=$ Rows on matrix $\alpha$

$\mathrm{j}=$ Column on matrix $\alpha$

3. Determine the priority weight scale

The criteria comparison matrix is evaluated and summed up in each column so that results are obtained for evaluating pairwise criteria comparisons. After that the priority weighting scale is done.

Information :

$$
w_{i}=\frac{1}{n} \sum_{j}^{i} a i j
$$

$\mathrm{n}=$ Number of criteria

$\mathrm{wi}=\mathrm{i}$ line average

\subsection{Technique For Others Reference by Similarity to Ideal Solution (TOPSIS)}

Technique for Others Reference by Similarity to Ideal Solution (TOPSIS) is one of the multicriteria decision making methods introduced by Yoon and Hwang (1981). This method uses the principle that the chosen alternative must have the closest distance from the positive ideal solution and the farthest from the negative ideal solution from a geometric point of view.

Positive ideal solutions are defined as the sum of all the best values that can be achieved for each attribute, while the negative-ideal solution consists of all the worst values achieved for each attribute. This method is widely used to resolve practical decision making. This is because the concept is simple and easy to 
understand, efficient computation, and has the ability to measure the relative performance of decision alternatives [11].

Steps of the TOPSIS method:

1. Normalize the matrix

Normalization of basic decision matrices using equations

$$
r_{i j}=\frac{x_{i j}}{\sqrt{\sum_{i=1}^{m} x_{i j}^{2}}} .
$$

Information :

$r_{i j}=$ Normalized matrix element $[\mathrm{i}][\mathrm{j}]$

$X_{i j}=$ Decision matrix element $\mathrm{X}$

2. Determine weighted matrices

Normalizing the rij matrix using a weight rating so that the normalized weight rating is obtained, using the equation

Information :

$$
y_{i j}=w_{i} \cdot r_{i j}
$$

$y_{i j}=$ Normalized matrix element $[\mathrm{i}][\mathrm{j}]$

$w_{i}=$ Weight [i] from the AHP process

3. Determine the ideal positive solution $(\mathrm{A}+)$ and the ideal negative solution (A-)

Determine the positive ideal solution $(\mathrm{A}+)$ and the ideal negative solution (A-) based on the weighted rating matrix value in the previous stage.

4. Determine the distance between weighted values for each alternative (D + ) and (D-)

Determine the distance between the weighted value of each alternative ideal positive solution and the negative ideal solution. To determine the distance between weighted values for each alternative to a positive ideal solution.

$$
\begin{aligned}
D_{i}^{+} & =\sqrt{\sum_{i=1}^{n}\left(y_{i}^{+}-y_{i j}\right)^{2}} \\
D_{i}^{-} & =\sqrt{\sum_{i=1}^{n}\left(y_{i}^{-}-y_{i j}\right)^{2}}
\end{aligned}
$$

Information :

$D_{i}^{+}=$The Distance of the alternative $\mathrm{i}$ with a positive ideal solution

$D_{i}^{-}=$The Distance of the alternative $\mathrm{i}$ with a negative ideal solution

$y_{i j}=$ Weighted normalized matrix element [i] [j]

$y_{i}^{+}=$Elements of a positive ideal solution

$y_{i}^{-}=$Elements of a negative ideal solution

5. Calculate preference values for each alternative (V)

Determine the preference value for each alternative with the equation

$$
V_{i}=\frac{D_{i}^{-}}{D_{i}^{-}+D_{i}^{+}}
$$

Information :

$V_{i}=$ The closeness of each alternative to the ideal solution 
In the design of this development research uses Unifed Modeling Language (UML) modeling, namely Use Case Diagram (UCD) and activity diagram. While the research method used is the type of research and development (Research and Development / R \& D) with the method or model of SDLC (System Development Life Cycle). This research method from SDLC uses the Linear Sequential Model / Waterfall Model. Waterfall Model describes a systematic and sequential approach to the software developed.

\section{RESULT AND DISCUSSION}

In this study the determination of criteria weights was carried out by the AHP method and at the ranking stage using the TOPSIS method. Based on the stages of each method, an example of the best selection of household labor services is implemented. From the results of interviews, observations, and questionnaires, the criteria used were the last education, experience, costs, attitudes, and skills. Alternative data like the table below.

Table 2. Alternative Data

\begin{tabular}{llccccc}
\hline No & Alternative & Last Education & Experience & Cost & Attitude & Skills \\
\hline 1 & Maid 1 & 4 & 3 & 2 & 1 & 2 \\
2 & Maid 2 & 2 & 5 & 2 & 1 & 2 \\
3 & Maid 3 & 4 & 5 & 3 & 1 & 2 \\
4 & Maid 4 & 5 & 2 & 1 & 1 & 2 \\
5 & Maid 5 & 1 & 3 & 2 & 1 & 2 \\
\hline
\end{tabular}

Calculation of weights using the AHP method as follows.

1) Make a paired comparison matrix

Determining the criteria weight here uses the value of the scale of pairwise comparison. Then the following criteria are obtained.

Table 3. Pairwise Comparison Matrix Data

\begin{tabular}{lccccc}
\hline \multicolumn{1}{c}{ Goal } & $\begin{array}{c}\text { Last } \\
\text { Education }\end{array}$ & Experience & Cost & Attitude & Skills \\
\hline Last Education & 1 & 0,33 & 0,33 & 1 & 1 \\
Experience & 3 & 1 & 0,33 & 1 & 1 \\
Cost & 3 & 3 & 1 & 1 & 1 \\
Attitude & 1 & 1 & 1 & 1 & 1 \\
Skills & 1 & 1 & 1 & 1 & 1 \\
Jumlah & 9 & 6,33 & 3,66 & 5 & 5 \\
\hline
\end{tabular}

2) Make a normalized matrix

Table 4. Normalized matrix

\begin{tabular}{lccccc}
\hline \multicolumn{1}{c}{ Goal } & Last Education & Experience & Cost & Attitude & Skills \\
\hline Last Education & 0,11 & 0,05 & 0,09 & 0,20 & 0,20 \\
Experience & 0,33 & 0,16 & 0,09 & 0,20 & 0,20 \\
Cost & 0,33 & 0,47 & 0,27 & 0,20 & 0,20 \\
Attitude & 0,11 & 0,16 & 0,27 & 0,20 & 0,20 \\
Skills & 0,11 & 0,16 & 0,27 & 0,20 & 0,20 \\
\hline
\end{tabular}


3) Calculate the average of each criteria

Last Education

$$
\mathrm{W} 1=\frac{0,11+0,05+0,09+0,20+0,20}{5}=0,13
$$

Experience

$$
\mathrm{W} 2=\frac{0,33+0,16+0,09+0,20+0,20}{5}=0,20
$$

Cost

Attitude

$$
\mathrm{W} 3=\frac{0,33+0,47+0,27+0,20+0,20}{5}=0,30
$$

Skills

$$
\mathrm{W} 4=\frac{0,11+0,16+0,27+0,20+0,20}{5}=0,19
$$

Affer the weight of 5

After the weight of each criterion is obtained, then it is done using the TOPSIS method. The steps taken in the TOPSIS method are as follows.

1) Making normalized decision matrix

$$
r_{i j}=\left[\begin{array}{lllll}
0,51 & 0,35 & 0,43 & 0,45 & 0,45 \\
0,25 & 0,59 & 0,43 & 0,45 & 0,45 \\
0,51 & 0,59 & 0,64 & 0,45 & 0,45 \\
0,64 & 0,24 & 0,21 & 0,45 & 0,45 \\
0,13 & 0,35 & 0,43 & 0,45 & 0,45
\end{array}\right]
$$

2) Making a weighted normalized decision matrix

$$
W_{i} \cdot r_{i j}=\left[\begin{array}{lllll}
0,07 & 0,07 & 0,13 & 0,08 & 0,08 \\
0,03 & 0,12 & 0,13 & 0,08 & 0,08 \\
0,07 & 0,12 & 0,19 & 0,08 & 0,08 \\
0,08 & 0,05 & 0,06 & 0,08 & 0,08 \\
0,02 & 0,07 & 0,13 & 0,08 & 0,08
\end{array}\right]
$$

3) Determine the matrix of the ideal positive solution $(\mathrm{A}+)$ and the ideal negative matrix (A-)

$$
\begin{aligned}
& \operatorname{Max}=\left[\begin{array}{lll}
0,08 & 0,120,190,080,08
\end{array}\right] \\
& \operatorname{Min}=[0,020,05 \text { 0,06 0,08 0,08] }
\end{aligned}
$$

4) Determine the distance between the values of each alternative with a matrix of positive and negative ideal solutions

$$
D_{i}^{+}=\left[\begin{array}{l}
0,08 \\
0,08 \\
0,02 \\
0,14 \\
0,10
\end{array}\right] \quad D_{i}^{-}=\left[\begin{array}{l}
0,08 \\
0,10 \\
0,15 \\
0,07 \\
0,07
\end{array}\right]
$$

5) Determine the preference value for each alternative

$$
\mathrm{V}=\left[\begin{array}{l}
0,51 \\
0,54 \\
0,90 \\
0,32 \\
0,40
\end{array}\right]
$$

From the preference value (V) it can be seen that V3 has the largest value with a value of 0.90 so it can be concluded that the best maid labor is a helper 3 . The output generated on the system is in accordance with manual calculations. Furthermore, the system testing stage is carried out through 4 testing methods, 
including black box testing, namely testing the system functional, white box testing, namely testing algorithms and system logic, usability testing, testing to determine the quality of the system, and testing user responses to determine the user's response to the system.

In the black box test, all functional systems are running properly and correctly according to the expected results.

In the white box test, the source code is tested with the aim of testing the process flow and logic. From the results of the test it was found that all the functions of the code contained in the system were running well and correctly. In the usability test, the test results show the average usability value using the system usability scale (SUS) method of $71.09 \%$. This shows that the usability level of the system is classified as good and can be accepted and used easily by the user. Finally, based on the user response test, the user response data gives a percentage of $87.5 \%$ with a good category and it can be concluded that the decision support system for selecting the "Best Helper" domestic workforce using the AHP and TOPSIS codes is feasible to use.

\section{CONCLUSION}

Based on the results and discussion it can be concluded that the application of the Analytical Hierarchy Process (AHP) method and the Technique for Other Reference By Similarity to Ideal Solution (TOPSIS) for the selection of "best helper" household workers with many different criteria (multi criteria) and many alternatives those who can provide recommendations for household workers according to the selected criteria. As for suggestions for future development, this research can be developed again using a combination of different decision support system methods.

\section{REFERENCES}

[1] Amstrong, G., \& Kotler. (2012). Prinsip-prinsip Pemasaran. Jakarta: Erlangga.

[2] Turban, E. (2005). Decision Support System and Intellegent System (Sistem Pendukung Keputusan dan Sistem Cerdas). Yogyakarta.

[3] Firdaus, I.H., Abdillah, G., \& Renaldi, F. (2016). Sistem Pendukung Keputusan Penentuan Karyawan Terbaik Menggunakan Metode AHP dan TOPSIS. Seminar Nasional Teknologi Informasi dan Komunikasi 2016 (SENTIKA 2016).

[4] Suratmi. (2016). Analisa Perbandingan Metod Weighted Product (WP) Dan Metode Analytical Hierarchy Process (AHP) Untuk Menentukan Penerima Bonus Pada Karyawan PT. Telesindo SHOP. Jurnal INFOTEK, 1(3). 
[5] Kumar, R., Padhi, S., Sidihartha, \& Sarkar, A. (2018). Supplier Selection Of An Indian Heavy Locomotive Manufacturer : An Integrated Approach Using Taguchi Loss Function, TOPSIS, and AHP. IIMB Management Review.

[6] Jayant, A., Gupta, P., Garg, S.K., \& Khan, M. (2014). TOPSIS-AHP Based Approach For Selection Of Reverse Logistics Service Provider: A Case Study Of Mobile Phone Industry. Procedia Engineering.

[7] Safitri, K., Waruwu, F.T., \& Mesran. (2017). Sistem Pendukung Keputusan Pemilihan Karyawan Berprestasi Dengan Menggunakan Metode Analytical Hierarchy Process (Studi Kasus: PT.Capella Dinamik Nusantara Takengon). Media Informatika Budidarma, 12-16.

[8] Rahim, Robbi, Supiyandi, \& Siahaan, A.P. (2018). TOPSIS Method Application for Decision Support System in Internal Control for Selecting Best Employees. Journal of Physics: Conference Series.

[9] Pressman, S.R., \& Maxim, B.R. (2015). Software Engineering-A Practitioner's Approach-Eighth Edition. USA: Mc Graw Hill Education

[10] Saaty, \& T.L. (2000). The Fundamentals of Decision Making and Priority Theory with the Analytical Hierarchy Process. Pittsburgh: RWS Publication University of Pittsburgh.

[11] Mundar, T. A. (2007). TOPSIS (Technique For Others Reference by Similarity to Ideal Solution). TOPSIS (Technique For Others Reference by Similarity to Ideal Solution). 